\title{
HAWKMOTH POLLINATION FACILITATES LONG-DISTANCE POLLEN DISPERSAL AND REDUCES ISOLATION ACROSS A GRADIENT OF LAND-USE CHANGE $^{1}$
}

\begin{abstract}
Land-use change is among the top drivers of global biodiversity loss, which impacts the arrangement and distribution of suitable habitat for species. Population-level effects include increased isolation, decreased population size, and changes to mutualistic and antagonistic interactions. However, the extent to which species are impacted is determined by life history characteristics including dispersal. In plants, mating dynamics can be changed in ways that can negatively impact population persistence if dispersal of pollen and/or seed is disrupted. Long-distance dispersal has the potential to buffer species from the negative impacts of land-use change. Biotic vectors of long-distance dispersal have been less frequently studied, though specific taxa are known to travel great distances. Here, we describe population genetic diversity and structure in a sphingophilous species that is experiencing habitat fragmentation through land-use change, Oenothera harringtonii W. L. Wagner, Stockh. \& W. M. Klein (Onagraceae). We use 12 nuclear and four plastid microsatellite markers and show that pollen dispersal by hawkmoths drives high gene flow and low population differentiation despite a range-wide gradient of land-use change and habitat fragmentation. By separating the contributions of pollen and seed dispersal to gene flow, we show that most of the genetic parameters are driven by hawkmothfacilitated long-distance pollen dispersal, but populations with small, effective population sizes experience higher levels of relatedness and inbreeding. We discuss considerations for conservation efforts for this and other species that are pollinated by long-distance dispersers.

Key words: Habitat fragmentation, hawkmoth pollination, isolation, land-use change, long-distance dispersal, Oenothera, Onagraceae, pollen dispersal, population genetics, seed dispersal.
\end{abstract}

Land-use change and habitat fragmentation remain important drivers of biodiversity loss globally (Sala et al., 2000; Fischer \& Lindenmayer, 2007; Haddad et al., 2015). Affected populations are known to experience reductions in population size and extent as well as increases in isolation and edge effects (Fahrig, 2003; Fischer \& Lindenmayer, 2007), which can impact population connectivity (Hadley \& Betts, 2009) and long-term population dynamics (Aguilar et al., 2006; Gonzalez et al., 2011; Brudvig et al., 2015; Haddad et al., 2015). When reductions in population size and increased isolation act in concert, mating patterns can be altered in ways that impact long-term population persistence (Ghazoul, 2005; Aguilar et al., 2006; Sork $\&$ Smouse, 2006; Breed et al., 2012, 2015). The extent to which species are impacted by land-use change depends on traits related to establishment (Leishman, 1999; Benson \& Hartnett, 2006), persistence, and dispersal (Cordeiro \& Howe, 2003; Ashworth et al., 2004; Kremen et al., 2007; Winfree et al., 2011). In flowering plants, connectivity is commonly facilitated via interactions with other organisms, such as pollination and seed dispersal (Jordano, 2010). Such interactions may be altered if any of the constituent players are affected by land-use change, which has consequences for plant mating dynamics and population persistence (Aguilar et al., 2006; Biesmeijer et al., 2006; Jordano, 2010; Potts et al., 2010; Magrach et al., 2014; Scheper et al., 2014; Breed et al., 2015; Emer et al., 2018).

It has been well established that mating patterns play an important role in the magnitude and distribution of genetic diversity (Jordano, 2010; Karron et al., 2012; Barrett \& Crowson, 2016; Whitehead et al., 2018). For biotically pollinated species, pollinators not only facilitate the fertilization of ovules, from their movement patterns they help determine the paternity, quality, and

1 Funding was provided by the National Science Foundation (DEB 1342873 to K. A. S. and J. B. F.), Colorado Native Plant Society (to K. A. S.), and the Chicago Botanic Garden Division of Plant Science and Conservation. The authors thank N. Wickett and two anonymous reviewers for feedback on previous versions of this manuscript. S. (Tass) Kelso and S. Olson facilitated fieldwork and access to population localities. S. Todd, K. West, and Q. Roberts provided assistance in the field and lab. S. Olson (USDA Forest Service) provided permission to conduct studies at Comanche National Grasslands, U.S.A.

2 Plant Science and Conservation, Chicago Botanic Garden, Glencoe, Illinois 60022, U.S.A. kskogen@chicagobotanic.org.

3 School of Sustainability, Arizona State University, Tempe, Arizona 85287, U.S.A.

4 School of Biological Sciences, Washington State University, Pullman, Washington 99164, U.S.A. 
future competitive ability of seedlings resulting from their floral visits. Land-use change can alter the abundance, movement, and foraging behavior of pollinators (Kremen et al., 2007; Hadley \& Betts, 2009; Schleuning et al., 2011; Winfree et al., 2011; Breed et al., 2012; Lander et al., 2013), which can change the mating patterns of the flowers visited (Aguilar et al., 2008; Eckert et al., 2010; Breed et al., 2015). Long-distance dispersal can mediate many of the impacts of fragmentation by maintaining population connectivity, gene flow, and recruitment in otherwise heterogeneous habitats (Damschen et al., 2008; Finger et al., 2014; Millar et al., 2014; Guidugli et al., 2016; Skogen et al., 2016). Pollen and seed dispersal has been documented over meters to kilometers in some systems (Sezen et al., 2005, 2009; Bacles, 2006; Ashley, 2010; Kramer et al., 2011), but the focus to date has been on wind pollination and biotic pollination in generalized pollination systems and in forest ecosystems (Lowe et al., 2015). However, species with specialized, biotic pollination systems may be more vulnerable to the impacts of land-use change (Kremen et al., 2007; Aizen et al., 2012; Weiner et al., 2014). The evaluation of both pollen and seed dispersal can help identify whether impacts may be dependent on the dispersal vectors involved, especially for taxa with different vectors of pollen and seed dispersal (Jordano, 2010).

Sphingophyly, or pollination involving hawkmoths (Sphingidae, Lepidoptera), is one such specialized pollination system (Johnson \& Steiner, 2000). Hawkmoths are expected to transport pollen over long distances (Stockhouse, 1973; Linhart \& Mendenhall, 1977; Haber \& Frankie, 1989; Bawa, 1990) and, therefore, may help mitigate the negative impacts of land-use change on the taxa they pollinate (Skogen et al., 2016). However, nocturnal pollination has received less attention than has diurnal pollination, and moth pollination remains understudied despite its importance for many plant species globally (Philipp et al., 2006; Devoto et al., 2011; Winfree et al., 2011; Macgregor et al., 2014). Declines in moths at local and regional scales are suspected to have resulted from anthropogenic factors including artificial light pollution and the loss of larval hosts associated with land-use change (Goldstein, 2010; Wagner, 2012; Fox, 2013; Fox et al., 2014; Macgregor et al., 2014; Knop et al., 2017; Hopkins et al., 2018). Such threats may limit the extent to which plant species pollinated by long-distance flyers such as hawkmoths may be buffered from land-use change.

Comparisons of long-distance dispersal and land-use change are limited in plants, with much of the literature focused on the standing genetic diversity of long-lived perennials, and trees in particular (Ashley, 2010; Buschbom et al., 2011; Robledo-Arnuncio, 2011;
Leonarduzzi et al., 2012; Gerber et al., 2014). However, the generation times of long-lived species may mask the realized contemporary impacts of land-use change and habitat fragmentation (Petit \& Hampe, 2006; Bacles \& Jump, 2011; Lowe et al., 2015). As the factors that impact patterns of genetic diversity may occur more rapidly in taxa with shorter generation times (Sork et al., 1999), more studies are needed that assess the genetic impact of land-use change on short-lived herbaceous plant species. Temporal fluctuations in population size (bottlenecks) are common in many annual and shortlived taxa. However, land-use change may limit the ability of populations to achieve sizes relative to otherwise natural conditions. Such limitations can have pronounced impacts on mating and subsequent genetic diversity and structure (Young et al., 1996; Breed et al., 2015). Nevertheless, most studies include a limited number of populations and rely on single year assessments of population sizes (Whitehead et al., 2018).

A comprehensive assessment of the processes impacted by land-use change is needed to better understand the drivers of change in contemporary systems and to develop more effective conservation strategies. Here we explore the genetic consequences of land-use change on the plant species Oenothera harringtonii W. L. Wagner, Stockh. \& W. M. Klein (Onagraceae), which is primarily pollinated by long-distance flyers (Hyles lineata [Fabricius], hawkmoths; Skogen et al., 2016; Rhodes et al., 2017) and has gravity-dispersed seeds (Wagner et al., 1985). As an annual, O. harringtonii allows for increased resolution of the impacts of landuse change and habitat fragmentation on genetic diversity. As an endemic species, $O$. harringtonii has a small range, making it feasible to study numerous populations across the entire range, which has experienced differing degrees of land-use change intensity. Previous work in this system indicates that land-use change has no detectable impact on pollination by hawkmoths (Skogen et al., 2016); however, explicit measures of plant mating events require a genetic approach (Aguilar et al., 2008; Ashley, 2010). Using nuclear and plastid microsatellites, we explicitly isolate the roles of long-distance (pollen) versus short-distance (seed) dispersal on genetic diversity. We compared patterns of gene flow (primarily pollen movement), genetic diversity, and population differentiation of 21 populations of $O$. harringtonii using 12 nuclear (seed and pollen dispersal) and four plastid microsatellite markers (seed dispersal, maternally inherited) to test the following hypotheses: (1) there is no detectable genetic differentiation due to high gene flow facilitated by long-distance dispersal of pollen by hawkmoths, and (2) land-use change will result in smaller effective population sizes, which will lead to a loss of genetic diversity and increased relatedness and inbreeding. 


\section{Methods}

STUDY SYSTEM

Oenothera harringtonii (Onagraceae) is a selfincompatible annual to semi-perennial herbaceous plant, which is endemic to the shortgrass prairies of south-central and southeastern Colorado and adjacent northwestern New Mexico, United States (Fig. 1A). The flowers of $O$. harringtonii exhibit classic hawkmoth pollination features including large, white corollas, long floral tubes with copious nectar, fragrance (Gregory, 1963, 1964; Fægri \& van der Pijl, 1966; Fenster et al., 2004), and flowers that open at dusk and wilt the following day, remaining open for 14 to 18 hours. Plants flower for four to six weeks in spring, and individual plants typically produce one to 10 flowers per night. Hawkmoths (Hyles lineata in particular) are the primary pollinators in this system, although solitary bees also visit in early evening and morning hours (Skogen et al., 2016). Paternity analyses have shown that hawkmoths facilitate outcrossing, with twice as many pollen donors as solitary bees (Rhodes et al., 2017). Seeds of $O$. harringtonii are gravity-dispersed, resulting in significant spatial genetic structure due to local topography (Rhodes et al., 2014).

Land-use change is believed to be a major threat to species persistence. South-central and southeastern Colorado have experienced rapid urban and agricultural development (Ladyman, 2005). All 29 known, extant populations of Oenothera harringtonii have been documented in areas with low vegetation cover that experience natural and human-induced disturbance (Skogen et al., 2016). However, range-wide studies reveal that land-use change has had no detectible effect on pollinator visitation and reproduction in this species (Skogen et al., 2016). We sampled 21 of the 29 extant populations spanning the geographic range of $O$. harringtonii and encompassing the range of human disturbance, from open rangeland to suburban residential properties (Fig. 1A, Table 1).

\section{MOLECULAR DATA}

Leaf tissue was collected in 2009, 2010, and 2012 from 13 to 30 individuals per population for a total of 680 individuals. Genomic DNA was extracted from silica-preserved leaf tissue following a modified cetyltrimethyl-ammonium bromide (CTAB) method (Khasa et al., 2000). DNA was quantified using a Nanodrop (Nano-Drop Technologies, Wilmington, Delaware, U.S.A.) and diluted to a final concentration of $50-100 \mu \mathrm{g} / \mathrm{ml}$. All individuals were genotyped using 12 nuclear microsatellite markers (Skogen et al., 2012; Rhodes et al., 2014) and four plastid microsatellite makers (Lewis et al., 2016). The nuclear microsatellite markers were fluorescently labeled (WellRed D2, D3, or D4, Sigma-Proligo, St. Louis, Missouri, U.S.A.) while the plastid samples were labeled using a two-step polymerase chain reaction (PCR) (Skogen et al., 2012; Lewis et al., 2016). PCR products were analyzed and scored using a CEQ 8000 Genetic Analysis System version 9.0 (Beckman Coulter, Brea, California, U.S.A.).

For the nuclear microsatellites, a subset of 200 individuals was re-extracted, and alleles were called blindly by a different person to test for repeatability and to measure genotyping error. Allele calls for each locus except two had an error rate below $2 \%$, which is unlikely to meaningfully bias data analysis (Dewoody et al., 2006). The error rate for two loci was 3\%-4\%, which was mainly associated with typographical error rather than erroneous calls by the sequencer software; once obvious errors were rescored and corrected the error rate fell below the $2 \%$ threshold. For plastid markers, rare haplotypes were confirmed by reamplifying samples and repeating length determination. To confirm the identity of similar length polymorphisms across our data, as well as to verify putatively shared alleles among individuals between populations, we sequenced one representative of each unique length polymorphism for every population with Sanger sequencing in both forward and reverse directions (Sequencher v5.3, Gene Codes Corp., Ann Arbor, Michigan, U.S.A.). Sequence data were initially auto-assembled using the program, and then manually verified. This allowed us to more confidently confirm the sequence for each of the observed length variants at a site in our dataset. Additionally, this approach uncovered allelic diversity between sites that was masked in the length-polymorphism dataset.

\section{LAND-USE CHANGE, FRAGMENTATION, AND POPULATION SIZE METRICS}

Land-use intensity was assessed using the 30-m National Land Cover Database 2011 (Jin et al., 2013; Homer et al., 2015) and was measured as the proportion of the total area characterized as Developed Low, Developed Medium, Developed High, and Developed Open Space within 1, 2.5, and $5 \mathrm{~km}$ of the center of each population, as described in Skogen et al. (2016). Population isolation was measured as the distance (kilometers) between a population and the next nearest population (Skogen et al., 2016). Habitat fragmentation metrics, total suitable area, a patch aggregation index, mean patch size, perimeter-to-area ratio, and patch cohesion for suitable habitat patches were also characterized within a 1-, 2.5-, and 5-km diameter from the center of the population as in Skogen et al. (2016). As Oenothera harringtonii occurs in an arid habitat with unpredictable winter and spring precipitation, and population size can fluctuate widely (Skogen et al., 2016; 

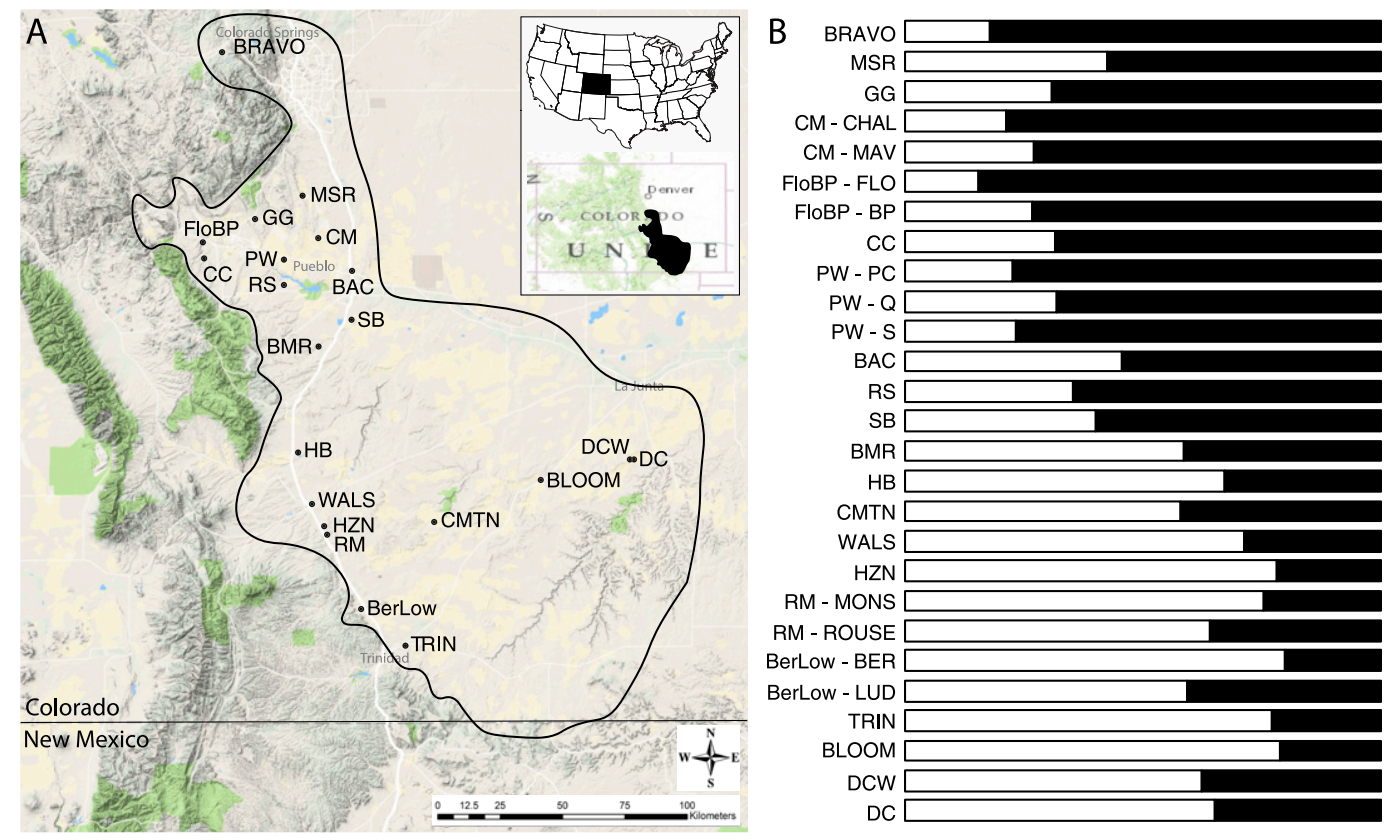

Figure 1. - A. Distribution of Oenothera harringtonii W. L. Wagner, Stockh. \& W. M. Klein in Colorado and adjacent New Mexico. Insets show the location of Colorado within the United States and the species distribution within Colorado. - B. Negligible population differentiation detected among 21 populations of $O$. harringtonii. Bar graph shows the population summary of $\mathrm{K}=2$ conceptual populations output from Structure.

Table 1), we collected up to five years of population census data to generate an accurate measurement of median population sizes. In most cases, populations were discrete and separated either by development or large distances $(>1 \mathrm{~km})$ without any plants between them. Consequently, most populations were defined as in Skogen et al. (2016). Five populations had several distinct patches of plants within a 1-km radius (BerLow, ChalMav, FloBP, Pueblo West, and RouseMons) and were evaluated for subpopulation differences (Table 1).

\section{STATISTICAL ANALYSES}

\section{Genetic parameters}

For the nuclear microsatellite data, the following measures of genetic diversity were calculated for each population in GenAlEx 6.5 (Peakall \& Smouse, 2012): including mean number of alleles per locus $\left(N_{a}\right)$, number of private alleles $\left(A_{P}\right)$, mean effective number of alleles per locus $\left(A_{e}\right)$, and expected heterozygosity $\left(H_{E}\right)$. Allelic richness $\left(A_{R}\right)$, adjusted for sample size, was calculated in FSTAT (Goudet, 1995). In addition, the nuclear microsatellite data were used to calculate the inbreeding coefficient $\left(F_{I S}\right)$ and pairwise relatedness $(R)$. Weir and Cockerham's (1984) estimates of Wright's $F_{I S}$ were calculated using GenAlEx 6.5, as was $R$ (Lynch \& Ritland, 1999), which was calculated for all sample pairs and was used to calculate the mean within- population relatedness. In addition, we used NeEstimator v2.01 (Do et al., 2014) to estimate genetic effective population size $\left(N_{e}\right)$ using the linkage-disequilibrium method. Waples and Do (2008) show that this model has good precision for microsatellite data, with limited sample size and number of markers, and for populations with relatively small effective sizes (100 to 200). For the plastid marker data, the total number of haplotypes and number of unique haplotypes were calculated for each population. Sequence data were initially auto-assembled using the program (Sequencher v5.3), and then manually verified. This allowed us to more confidently identify haplotype sequences for each of the observed length variants at a site in our dataset. This approach uncovered allelic diversity between sites that was masked in the length-polymorphism dataset.

\section{Isolation by distance}

To determine if hawkmoth pollination or seed dispersal drives low genetic differentiation within this species, we compared pairwise genetic distance $\left(F_{S T}\right)$ of nuclear data to Euclidean distance. For the nuclear data, Weir and Cockerham's $F_{S T}$ (Weir \& Cockerham, 1984) was calculated between populations using the program SPAGeDi (Hardy \& Vekemans, 2002). Although $G_{S T}$ (Hedrick, 2005) and $D$ (Jost, 2008) are thought to circumvent some statistical problems with 


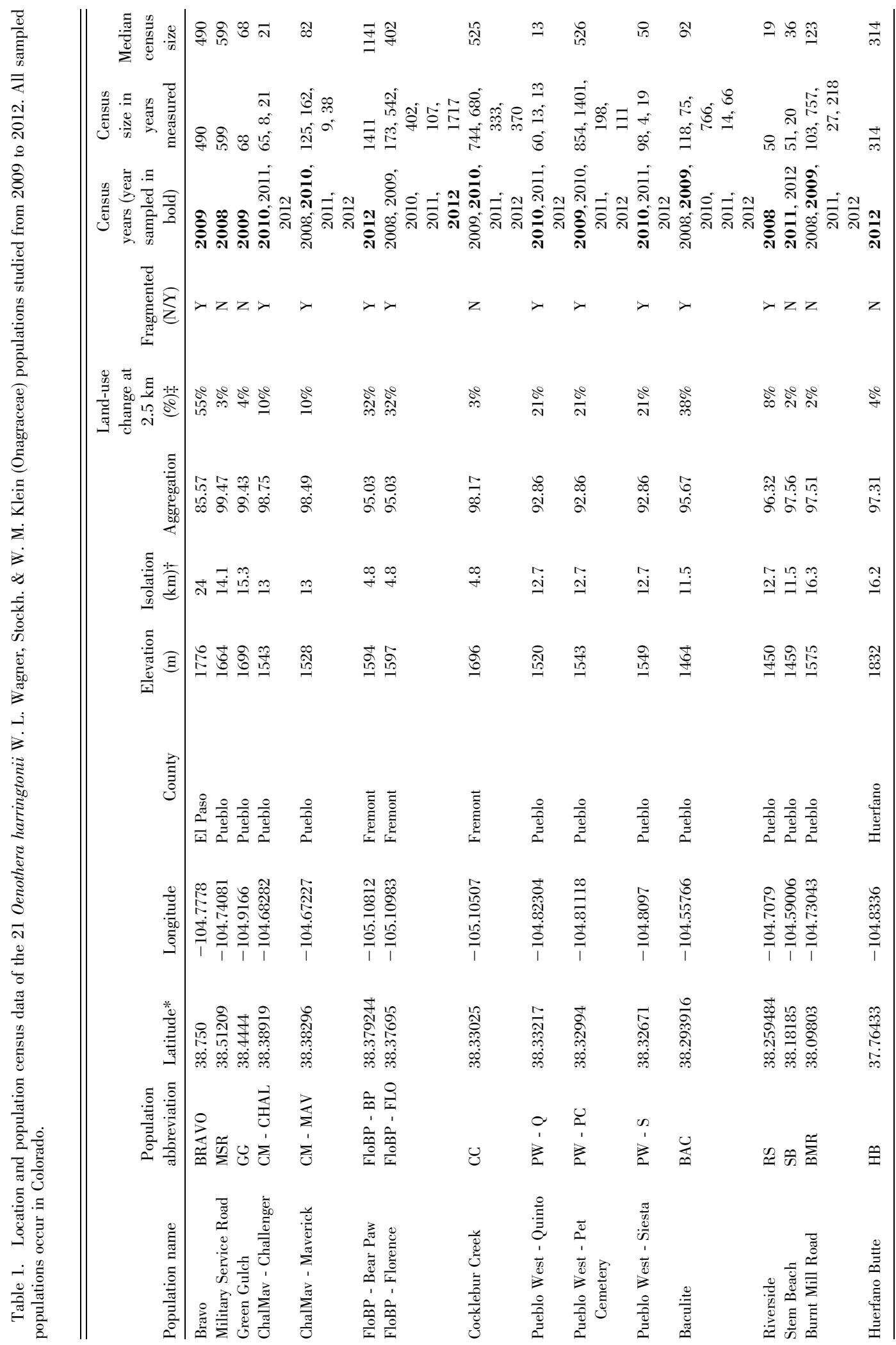




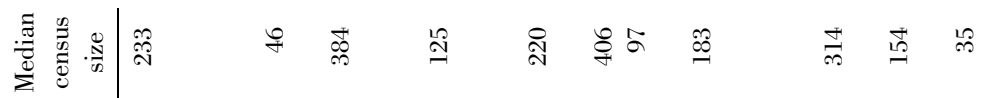

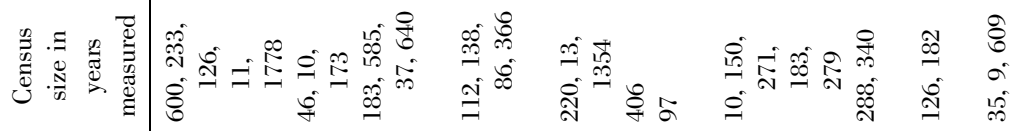

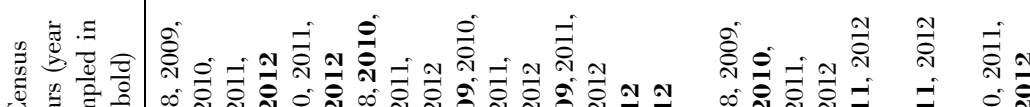

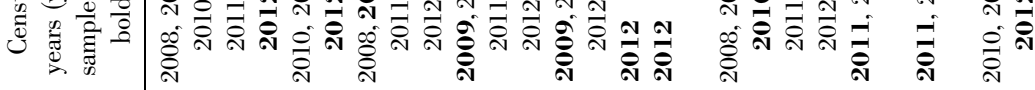

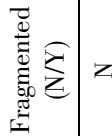

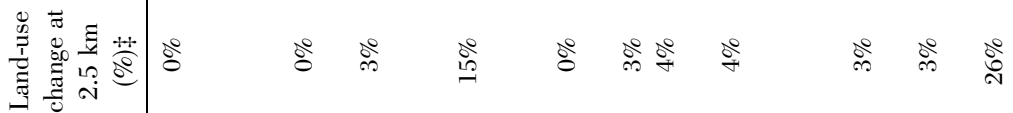

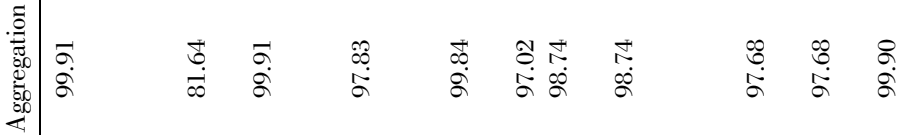

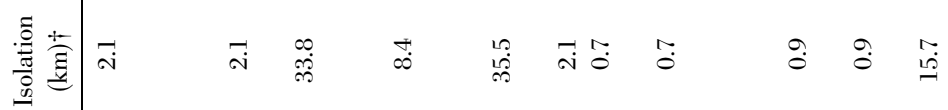

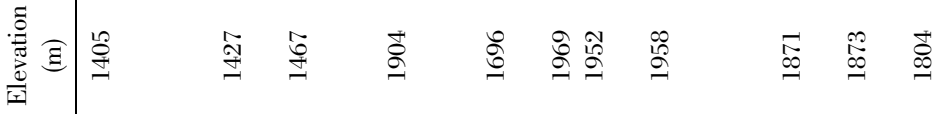

言

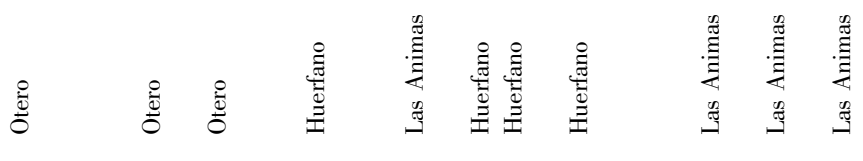

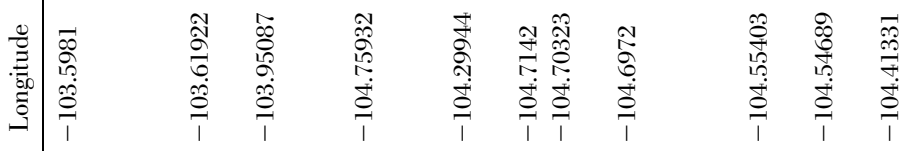

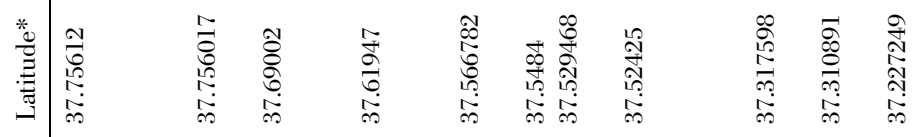

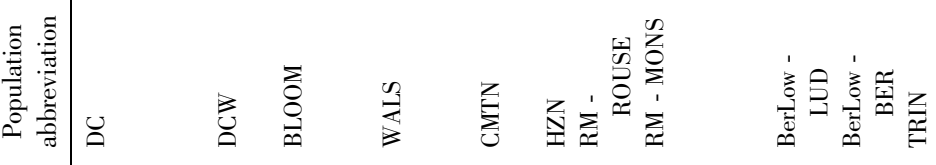


$F_{S T}$, recent studies have affirmed that $F_{S T}$ and its equivalents remain a better statistical measure for making demographic inferences (Meirmans et al., 2011; Meirmans \& Hedrick, 2011; Whitlock, 2011). To determine if there was any evidence of isolation by distance, all pairwise genetic distances were regressed against the $\log$ of Euclidean distance (kilometers) using a Mantel test in GenAlEx. In addition, analysis of molecular variance (AMOVA) was used to partition genetic differentiation within and among populations across the range, also in GenAlEx. Structure v2.2 (Pritchard et al., 2000; Falush et al., 2007) was used to identify range-wide genetic population subdivision (number of genetic clusters, K). We carried out 20 independent runs per $\mathrm{K}$ using a burn-in period of $10^{6}$ and collected data for $10^{6}$ iterations for $\mathrm{K}=1$ to 31 as recommended by Evanno et al. (2005). Structure Harvester Web v0.6.94 (Earl \& vonHoldt, 2012) was used to determine the minimum value of $\mathrm{K}$ that can explain the data using the rate of change in the log likelihood probability as detailed in Evanno et al. (2005).

For plastid marker data, a distance matrix was calculated for all individuals based on both nucleotide substitution and indel characters. Indels present in the dataset were coded with the program SeqState (Müller, 2005) using the modified complex coding of Müller (2006), which allowed us to calculate transition costs from one gap-nucleotide state to another. We then tested for signatures of genetic structure within and among populations with a nested AMOVA based on the total character differences in the distance matrix using the program GenAlEx 6.5 with the "haploid" setting. As plastid markers are maternally inherited, we compared isolation by distance for both nuclear and plastid markers to determine the relative contribution of pollen versus seed dispersal.

Land-use change, fragmentation, and population size metrics

All landscape metrics were tested for normality, and were $\log$ transformed to correct for skewness. All analyses were conducted in R 3.5.3 (R Core Team, 2019). The panel.cor and cor.test functions were used to identify landscape metrics that were highly correlated. Once any independent landscape metrics were identified, general linear models were used to assess their relationships with genetic diversity parameters $\left(N_{a}, H_{E}\right.$, $A_{P}, \% A$, and $\left.A_{R}\right)$, inbreeding $\left(F_{I S}\right.$ and $\left.R\right)$, and genetic differentiation (IBD). The stepAIC function within the MASS package (Venables \& Ripley, 2002) was used to choose the best fit model by Akaike information criterion (AIC) in a stepwise algorithm using a backward elimination general-linear model and correlation tests. The best model was then tested against the null model (no relationship) using ANOVA. For significant models, the relative importance of each variable in model was tested using the relaimpo package (Grömping, 2006) in $\mathrm{R}$, which uses averaging sequential sum of squares to order significant variables in linear model.

\section{Results}

\section{GENETIC PARAMETERS}

The nuclear and plastid microsatellite markers revealed substantial genetic diversity within Oenothera harringtonii (Table 2) for a narrow endemic. There was large variation by population for all parameters assessed, including mean number of alleles per locus ( $N_{a}$, range 5.8-11.8), number of private alleles $\left(A_{P}\right.$, 0-6), allelic richness $\left(A_{R}, 4.7-6.7\right)$, mean effective number of alleles per locus $\left(A_{e}, 3.8-6.8\right)$, and expected heterozygosity $\left(H_{E}, 0.66-0.81\right)$. Similarly, the four plastid microsatellites identified 22 haplotypes range wide (Table 2), although nearly half the populations ( $\mathrm{N}=12$ ) were comprised of a single haplotype, and nearly half $(\mathrm{N}=13)$ possessed unique haplotypes not found in any other population.

Across the range, the inbreeding coefficient ranged from very low $\left(F_{I S}=0.01\right)$ to moderately high $\left(F_{I S}=\right.$ 0.16), especially considering Oenothera harringtonii is a self-incompatible species (Skogen et al., 2016; Table 2). Similarly, all populations showed a highly significant $(P<0.001)$ mean relatedness $(\bar{R})$ between all individuals when compared across the full dataset; the one exception was Military Service Road, which was less significant $(P<0.01)$. Interestingly, there was weak to no correlation between relatedness and inbreeding coefficient $(\mathrm{r}=0.16)$. The effective population sizes calculated using the linkage-disequilibrium method (Do et al., 2014) were within the range of recorded census sizes for each population (Table 2). For this reason, it was not surprising that genetic effective population size ( $N_{e}$ est) showed a positive correlation $(\mathrm{r}=0.54)$ with census size. As predicted by Waples and Do (2008), the accuracy was best for smaller populations and when there were more than two years of census data. For two populations (David's Canyon and Military Service Road), the variation was larger than the actual estimate of $N_{e}$, which is interpreted as very large $N_{e}$ (Waples \& Do, 2008). This is consistent with the census data as these two populations were some of the largest documented for the species.

For the five populations comprised of multiple subpopulations (Berlow, ChalMav, FloBP, Pueblo West, and RouseMons), differences in genetic indices between subpopulations were substantial, and thus were preserved as independent units. As this created an imbalance in sample size for some populations, we 


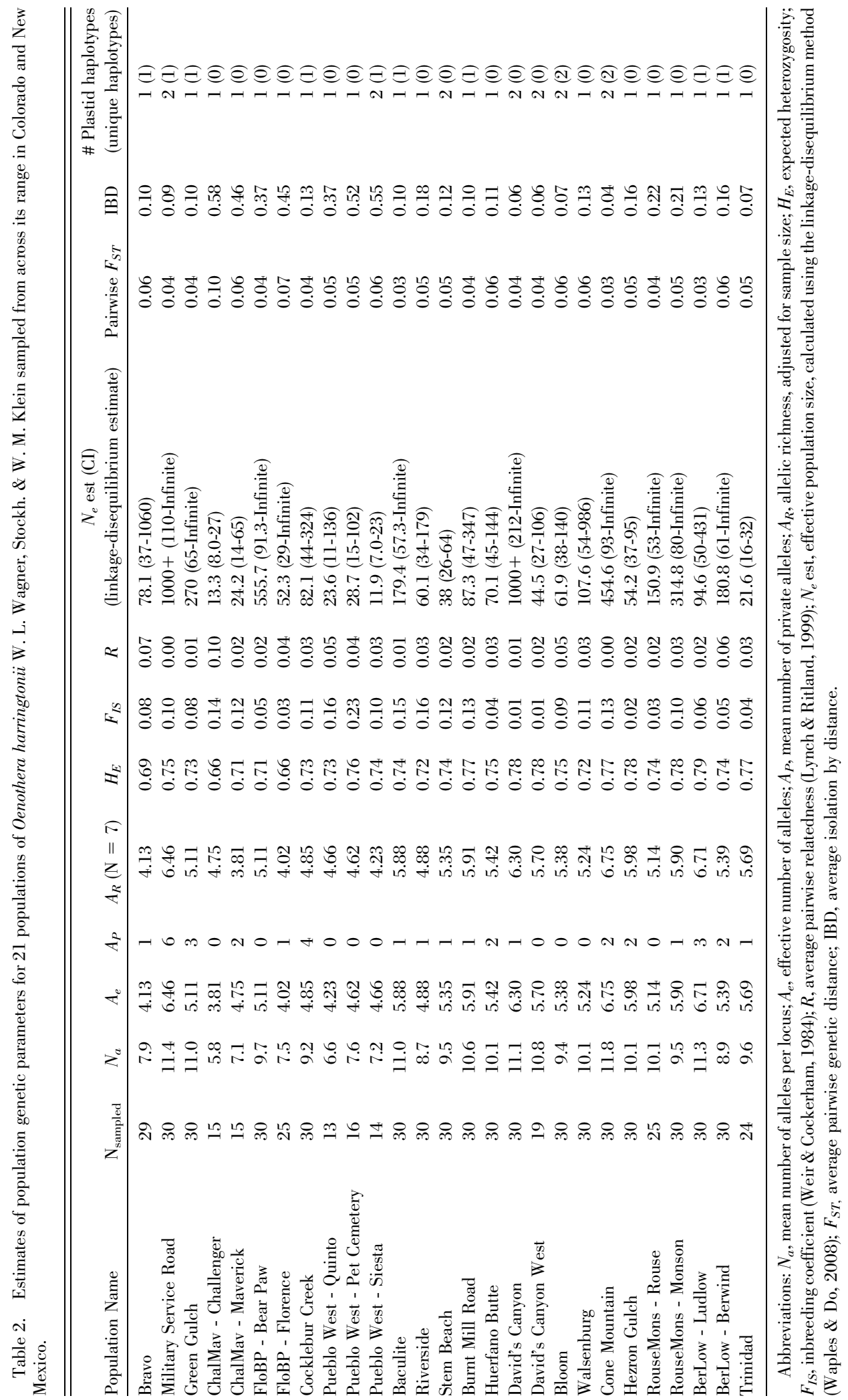


tested for correlations between sample size and genetic indices. Most of the indices showed only a weak correlation with sample size $(\mathrm{r}<0.41)$, with the exception of number of alleles $\left(N_{a}, \mathrm{r}=0.72\right)$, allelic richness $\left(A_{R}, \mathrm{r}=0.56\right)$, and effective number of alleles $\left(A_{e}, \mathrm{r}=\right.$ 0.56). However, samples size was not correlated with any landscape metrics except median census size.

\section{ISOLATION BY DISTANCE}

The genetic distance between most population pairs ranged from very low $\left(F_{S T}=0.01\right)$ to moderately low $\left(F_{S T}=0.12\right)$, although one population pair showed higher genetic distance than the rest (Burnt Mill RoadRiverside, $F_{S T}=0.16$ ). A mantel test revealed a weak but positive isolation by distance that was detected when we compared pairwise genetic distance to geographic distance $\left(r^{2}=0.16\right)$. The weak relationship was associated with a large range of pairwise genetic distances over small geographic distances (Fig. 2, Appendix 1). The low genetic differentiation in the nuclear microsatellite data was supported by the Bayesian analysis in Structure 2.2 where an optimal K value of 2 or less was identified as the best fit of data in Structure Harvester (Fig. 1). When all populations were compared at $\mathrm{K}=2$, both genetic clusters were found in all individuals; however, there was a clinal shift in percent assignment to a cluster from north to south. This weak cline supports the observed isolation by distance showing weak correlation. The AMOVA also supported the observed low differentiation, with high genetic variation found within populations (96\%) and a very low percentage $(4 \%)$ of genetic diversity in the species due to differences between populations. By contrast, the plastid microsatellite markers revealed strong genetic separation between populations. Across 674 of the 680 individuals, 21 haplotypes were detected consisting of variation in both single nucleotide polymorphisms (SNPs) and indels. A total of 20 of the 21 populations had only a single haplotype present, and of those, six populations (Baculite, BerLow-Berwind, BerLow-Ludlow, Bravo, Burnt Mill Road, and Cocklebur Creek) had haplotypes that were unique in the dataset. An AMOVA of chloroplast DNA (cpDNA) genetic diversity found most of the variation $(96 \%)$ was between populations.

\section{LAND-USE CHANGE AND FRAGMENTATION METRICS}

Not surprisingly, there were few differences between the landscape metrics when moving from 1-km to 2.5$\mathrm{km}$ and 5-km radii, and many were highly correlated $\left(r^{2}>0.7\right)$. Therefore, we restricted our analysis to four metrics that showed the lowest correlation to each other $\left(r^{2}<0.4\right)$. These included total development and patch aggregation index within a $2.5-\mathrm{km}$ radius, population isolation, and median census size. Respectively, these metrics cover area of habitat loss, habitat distribution, isolation, and population size. Using these four metrics we found that all but isolation explained genetic diversity to varying degrees. Expected heterozygosity $\left(H_{E}\right)$ was best explained by total development $(\mathrm{F}=6.69, P=$ $0.016)$, while allelic richness $\left(A_{R}\right)$ was best explained by both total development and aggregation index $(\mathrm{F}=$ 8.71, $P=0.001)$. Meanwhile, number of alleles $\left(N_{a}\right)$ and effective number of alleles $\left(A_{e}\right)$ were best explained by median census size, total development, and aggregation index $(\mathrm{F}=5.37, P=0.006$ and $\mathrm{F}=6.90, P=$ 0.002 , respectively). Because the number of alleles, allelic richness, and effective number of alleles were correlated with sample size, it is difficult to be certain if this result is an artifact of sampling or driven by landscape metrics, especially median census size, which was also correlated with sample size $(\mathrm{r}=0.54)$. However, the genetic effective population size $\left(N_{e}\right)$ in these four populations was also best explained by median census size, total development, and aggregation index $(\mathrm{F}=6.20, P=0.003)$, suggesting that these factors play important roles in limiting population size.

Despite high levels of gene flow, the factor that best explained estimates of the inbreeding coefficient $\left(F_{I S}\right)$ was isolation ( $\mathrm{F}=8.97, P=0.006)$, the distance from the center of the focal population to that of the closest adjacent population. This was the only genetic parameter for which isolation was an explanatory variable. This suggests isolation is a better indicator of potential inbreeding than population size. By contrast, mean relatedness $(\bar{R})$ was best explained by median population size and degree of aggregation, while pairwise isolation by distance was best explained by median census size only, although both models showed weak statistical significance $(\mathrm{F}=5.10, P=0.03$ and $\mathrm{F}=$ $2.50, P=0.13$, respectively).

\section{Discussion}

Our nuclear genetic data support the hypothesis that pollen dispersal by hawkmoths drives high gene flow and low population differentiation, despite a range-wide gradient of land-use change and habitat fragmentation. By separating the contributions of pollen and seed dispersal to gene flow, we show that most of the genetic parameters are driven by hawkmoth-facilitated, longdistance pollen dispersal (Skogen et al., 2016; Rhodes et al., 2017) and that there is limited spatial genetic structure resulting from gravity-dispersed seeds (Rhodes et al., 2014). Despite low population differentiation and high visitation rates (Skogen et al., 2016), we did observe lower diversity, increased relatedness, and inbreeding in populations with higher isolation, and those that have experienced moderate to high levels of land-use change. 


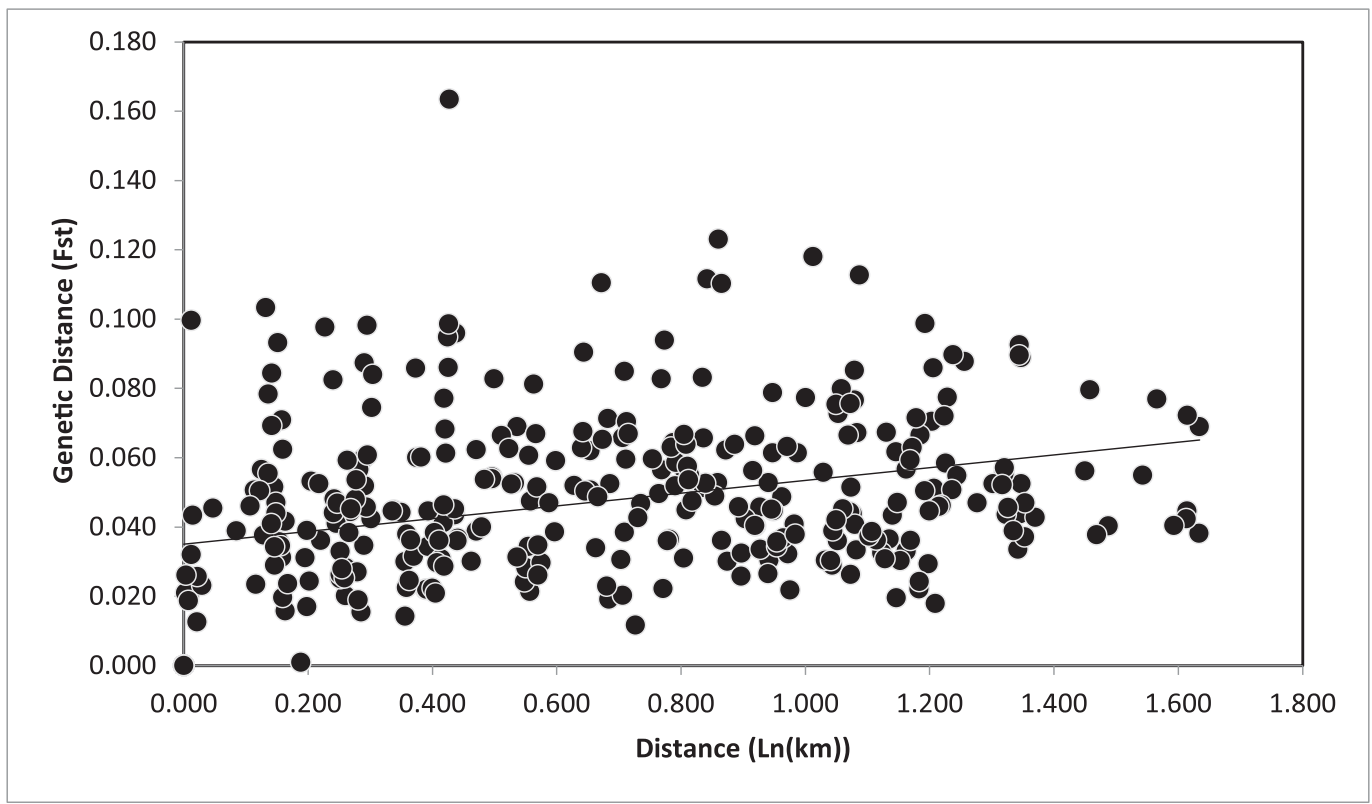

Figure 2. Limited isolation by distance $\left(r^{2}=0.16\right)$ was detected using a comparison of genetic distance $\left(F_{\mathrm{ST}}\right)$ and geographic distance (log (kilometers)).

This study is one of a few to investigate the impact of landuse change and habitat fragmentation on hawkmothpollinated plants (Finger et al., 2014), and one of the first on a short-lived species, where short generation times provide increased sensitivity in detecting changes in the distribution and abundance of genetic diversity across the range of a species. Genetic tools allow us to identify impacts that are not observable using other metrics, namely pollinator observations, as prior work in this system showed that reproduction was not impacted by land-use change (Skogen et al., 2016).

Pollination limitation has been cited as the proximate cause of reproductive failure resulting from land-use change and habitat fragmentation (Young et al., 1996; Aguilar et al., 2006; Vanbergen \& The Insect Pollinators Initiative, 2013). Pollinators that move long distances can serve as agents of selection on traits important to pollinator attraction and fidelity (Gómez \& Zamora, 2000; Totland, 2001; Boyd, 2004; Rey et al., 2006) while simultaneously constraining adaptive divergence of populations through gene flow, reducing differences among populations (inbreeding, population differentiation, maintaining genetic diversity; Haldane, 1948; Ehrlich \& Raven, 1969; Slatkin, 1985; Lenormand, 2002). In this system, hawkmoths are uniquely reliable pollinators in space and time (Skogen et al., 2016) and contribute to extensive long-distance pollen dispersal (low $F_{S T}$ ), resulting in negligible population differentiation (Aguilar et al., 2019). In addition, we identified high levels of genetic diversity (nuclear and plastid) among populations of Oenothera harringtonii, a narrow endemic. This is in contrast to the lower genetic diversity documented in many species with restricted geographic distributions (endemics) when compared to their more widespread congeners (Hamrick \& Godt, 1996; Nybom, 2004; Piñeiro et al., 2009; though see Gitzendanner \& Soltis, 2000; Cole, 2003). Furthermore, while many annual plant species have lower outcrossing rates than longer-lived species (Vogler \& Kalisz, 2001; Charlesworth, 2006), we observed high outcrossing rates in this study.

In contrast to the pattern of genetic diversity revealed by nuclear markers, plastid markers showed limited gene flow via seed dispersal, which is consistent with expectations for species with gravity-dispersed seeds (Hamilton \& Miller, 2002; Dyer, 2007; Cánovas et al., 2015). The discrepancy we observe between pollen and seed dispersal has been documented in other taxa that experience long-distance pollen dispersal and limited seed dispersal (Grivet et al., 2009; Jordano, 2010; Finger et al., 2014). The seed bank of annual plant species can introduce complications for interpreting genetic diversity and structure, similar to those of perennial or long-lived species. Seeds of Oenothera harringtonii can survive in the seed bank for up to 10 years (pers. obs.) and possibly longer. Thus, the seed bank represents another mode for the influx of new genotypes, as individuals that make up a population in any one year are the result of seeds formed in years with different pollination environments and mating 
dynamics. In addition, it can be difficult to distinguish between populations that are always small versus those that have experienced bottlenecks or were recently founded.

Isolating the roles of both pollen and seed dispersal in facilitating or limiting gene flow is rarely assessed in concert. However, the dispersal of pollen and seed, often through different vectors, may be impacted by land-use change and fragmentation in different ways (Aguilar et al., 2008, 2019; Jordano, 2010). Many studies draw conclusions about the dispersal agent by using indirect evidence associated with natural history characteristics. For example, extremely long-distance gene flow $(22 \mathrm{~km})$ in heart of palm trees (Euterpe edulis Mart., Arecaceae) was attributed to seed rather than pollen dispersal due to the short foraging distances $(50-100 \mathrm{~m})$ of the primary pollinator, the small bee Trigona spinipes (Fabricius) and the fact that nearly 22 bird species were considered potential seed dispersers (Gaiotto, 2003). The inclusion of data and/or vectors that contribute to pollen and seed dispersal can provide insight into the roles each plays in the distribution of genetic diversity and how each component may be impacted by anthropogenic threats, especially when different vectors are involved. In addition to being highly reliable pollinators, in this system, hawkmoth visitation rates are no different in populations with little to no land-use change than those with moderate to high (Skogen et al., 2016). Combined with our genetic data, this suggests that the negative consequences of land-use change on hawkmoths (Hyles lineata in particular) have not altered their abundance or behavior in ways that impact their visitation rates to Oenothera harringtonii flowers, nor the import of pollen from outside populations, but this remains to be tested.

While some studies have shown that nocturnal pollinators can be relatively ineffective at moving pollen between isolated subpopulations (Barthelmess et al., 2006), our results document the opposite and are consistent with what has been observed in the limited assessments of genetic diversity in hawkmothpollinated taxa. In a detailed within-population study of Oenothera harringtonii, hawkmoth pollination resulted in higher outcrossing rates via the transfer of twice as many realized mates (pollen donors) as did solitary bee visits (Rhodes et al., 2017). Similarly, a comparison of two closely related Oenothera L. species found that the hawkmoth-pollinated species $(O$. hartwegii Benth. subsp. filifolia (Eastw.) W. L. Wagner \& Hoch) experienced higher outcrossing rates, more gene flow, and less population differentiation at both local (subpopulation) and regional scales than did the beepollinated species $(O$. gayleana B. L. Turner \& M. J. Moore; Lewis, 2015). Lastly, in the only other published study investigating the role of hawkmoth pollination in a fragmented landscape, Finger et al. (2014) found that long-distance pollen dispersal by hawkmoths was common and extensive in Glionnetia sericea (Baker) Tirveng (Rubiaceae), a tree species endemic to the Seychelles islands. Importantly, the $F_{S T}$ values reported here are more consistent with those of wind(Govindaraju, 1988; Franks et al., 2004; Buschbom et al., 2011; Robledo-Arnuncio, 2011) and hawkmothpollinated taxa (Herrera \& Bazaga, 2008; Brunet et al., 2012; Finger et al., 2014) than those pollinated by insects, or even longer distance-dispersing bats and birds (Nassar et al., 2001, 2003; Hughes et al., 2007; Kramer et al., 2011).

While hawkmoths have been documented to travel over great distances (400 m to $32 \mathrm{~km}$; Stockhouse, 1973; Linhart \& Mendenhall, 1977; Bawa, 1990), few studies have investigated the genetic consequences of this longdistance dispersal for plant species (Finger et al., 2014; Lewis, 2015). Despite high levels of gene flow, we documented higher levels of relatedness and inbreeding (here, biparental inbreeding as Oenothera harringtonii is self-incompatible, while crosses between siblings are fertile; Skogen et al., 2016) in more isolated populations. The increase in inbreeding may be attributed to a number of factors, including gravity-dispersed seeds (plastid data showing population differentiation presented here), lower mate (pollen) diversity under bee pollination (Rhodes et al., 2017), and resulting spatial genetic structure (Rhodes et al., 2014). In addition, hawkmoths commonly visit many flowers on the same plant and many plants in a population, causing further increases in local gene flow. Combined with spatial genetic structure, the incidence of biparental inbreeding within patches of plants and in smaller populations may be high. This may be exacerbated in years with extremely low population sizes where mating events occur between a few parents, increasing the likelihood that offspring are closely related.

We also detected lower genetic diversity and smaller effective population sizes in populations surrounded by greater development and lower median census sizes. It is likely that this drop in genetic diversity is associated with drift due to smaller population sizes. In this species, we have recorded large fluctuations in population sizes, with some showing a 100-fold increase between years. However, in many fragmented populations there is limited spatial capacity to support the occasional larger population. In combination, smaller population sizes and restricted potential for occasional population expansions will increase the likelihood of genetic bottlenecks, further reducing genetic diversity. In our data, this is supported by the smaller effective population size observed in populations with more landuse change, suggesting that these populations either contain fewer individuals over time and/or comparatively fewer mating events. In these populations, it is 
possible that long-distance pollen import may not be enough to overcome the genetic consequences of limited population sizes. We were able to detect this difference in genetic diversity and effective population sizes because Oenothera harringtonii is an annual species and sufficient time has passed for isolation to occur, which can be masked in longer-lived species (Lowe et al., 2015). Other factors may be at play, including bottlenecks due to dramatic fluctuations in population sizes between years, founder events, and/or small effective population sizes.

Our results suggest that the pollination mechanism and pollinator biology play an important role in maintaining connectivity in the face of changing landscapes and environments but cannot overcome consequences of small population sizes. Notably, the negative impacts of land-use change may take longer to manifest in species that experience long-distance dispersal, such as those pollinated by long-distance dispersing pollinators. However, if future conditions change in ways that impact vectors of long-distance dispersal, the import of pollen from outside populations may not be enough to overcome challenges associated with changes to pollinator identity and behavior, changes in mating patterns due to increased isolation, reductions in population size, and spatial genetic structure. Such challenges could lead to inbreeding depression and threaten population persistence (Kremen et al., 2007; Aizen et al., 2012; Breed et al., 2012; Aguilar et al., 2019).

Together, these data document that hawkmoths, known to pollinate species in over 75 plant families (Grant, 1983, 1985; Fox et al., 2014; Macgregor et al., 2014), are an important yet understudied pollinator functional group that can make major contributions to long-distance dispersal. Our work provides important context for understanding the nuances of how anthropogenic change may or may not impact plant mating dynamics and therefore the ability of populations and species to persist into the future. Additionally, our work suggests that sphingophilous plant species may be buffered from some of the negative impacts of land-use change and habitat fragmentation.

Conservation efforts should target pollinators and the resources they need to support various life history stages (Kremen et al., 2007; Kovács-Hostyánszki et al., 2017). In particular, hawkmoth and other lepidopteran pollinators commonly have different needs for larval and adult phases, and efforts to support them will include restoring native plant communities and reducing the use of pesticides and herbicides (Fox et al., 2014; Macgregor et al., 2014). For nocturnal pollinators including moths, reductions in light pollution may reduce increases in mortality (Frick \& Tallamy, 1996), predation (Svensson \& Rydell, 1998; Acharya \& Fenton, 1999; Frank, 2006), and altered behaviors (Pfrimmer,
1955; Nemec, 1969; Sower et al., 1970; Brown, 1984) that result from moths being attracted to artificial lights. Without such efforts, plant mating patterns may be altered by land-use change in ways that reduce fitness and the ability of populations to be resilient to anthropogenic change (Knop et al., 2017; Hopkins et al., 2018). In addition, more explicit approaches focused on realized mating events (parentage assessments, etc.) may provide more direct assessments (Breed et al., 2015; Rhodes et al., 2017) relevant to isolating the relative contributions of pollen and seed dispersal to gene flow, allowing for a better understanding of how mating dynamics are negatively impacted. In addition, we still know little of the impact that anthropogenic change can have on pollinators and seed dispersers, especially for insect taxa whose population sizes fluctuate under natural/undisrupted conditions. An underlying assumption of our work is that hawkmoths travel great distances and that they are not negatively impacted by land-use change. Future work on the distribution and abundance of hawkmoths using field-collected data, molecular markers, and/or isotopic signatures would allow for a test of this hypothesis.

\section{Literature Cited}

Acharya, L. \& M. B. Fenton. 1999. Bat attacks and moth defensive behavior around street lights. Canad. J. Zool. 77: 27-33.

Aguilar, R., L. Ashworth, L. Galetto \& M. A. Aizen. 2006. Plant reproductive susceptibility to habitat fragmentation: Review and synthesis through a meta-analysis. Ecol. Lett. 9: 968-980.

Aguilar, R., M. Quesada, L. Ashworth, Y. Herrerias-Diego \& J. Lobo. 2008. Genetic consequences of habitat fragmentation in plant populations: Susceptible signals in plant traits and methodological approaches. Molec. Ecol. 17: 5177-5188.

Aguilar, R., E. J. Cristóbal-Pérez, F. J. Balvino-Olvera, M. Aguilar-Aguilar, N. Aguirre-Acosta, L. Ashworth, J. A. Lobo, et al. 2019. Habitat fragmentation reduces plant progeny quality: A global synthesis. Ecol. Lett. 22: 1163-1173.

Aizen, M. A., M. Sabatino \& J. M. Tylianakis. 2012. Specialization and rarity predict nonrandom loss of interactions from mutualist networks. Science 335: 1486-1489.

Ashley, M. V. 2010. Plant parentage, pollination, and dispersal: How DNA microsatellites have altered the landscape. Crit. Rev. Pl. Sci. 29: 148-161.

Ashworth, L., R. Aguilar, L. Galetto \& M. A. Aizen. 2004. Why do pollination generalist and specialist plant species show similar reproductive susceptibility to habitat fragmentation? J. Ecol. 92: 717-719.

Bacles, C. F. E. 2006. Effective seed dispersal across a fragmented landscape. Science 311: 628.

Bacles, C. F. E. \& A. S. Jump. 2011. Taking a tree's perspective on forest fragmentation genetics. Trends Pl. Sci. 16: 13-18.

Barrett, S. C. H. \& D. Crowson. 2016. Mating systems in flowering plants. Pp. 473-479 in Encyclopedia of Evolutionary Biology. Elsevier, Amsterdam.

Barthelmess, E. L., C. M. Richards \& D. E. McCauley. 2006. Relative effects of nocturnal vs diurnal pollinators and distance on gene flow in small Silene alba populations. New Phytol. 169: 689-698. 
Bawa, K. S. 1990. Plant-pollinator interactions in tropical rain forests. Annual Rev. Ecol. Syst. 21: 399-422.

Benson, E. J. \& D. C. Hartnett. 2006. The role of seed and vegetative reproduction in plant recruitment and demography in tallgrass prairie. Pl. Ecol. 187: 163-178.

Biesmeijer, J. C., S. P. M. Roberts, M. Reemer, R. Ohlemüller, M. Edwards, T. Peeters, A. P. Schaffers, et al. 2006. Parallel declines in pollinators and insect-pollinated plants in Britain and the Netherlands. Science 313: 351-354.

Boyd, A. E. 2004. Breeding system of Macromeria viridiflora (Boraginaceae) and geographic variation in pollinator assemblages. Amer. J. Bot. 91: 1809-1813.

Breed, M. F., M. H. K. Marklund, K. M. Ottewell, M. G. Gardner, J. B. C. Harris \& A. J. Lowe. 2012. Pollen diversity matters: Revealing the neglected effect of pollen diversity on fitness in fragmented landscapes. Molec. Ecol. 21: 5955-5968.

Breed, M. F., K. M. Ottewell, M. G. Gardner, M. H. K. Marklund, E. E. Dormontt \& A. J. Lowe. 2015. Mating patterns and pollinator mobility are critical traits in forest fragmentation genetics. Heredity 115: 108-114.

Brown, L. N. 1984. Population outbreak of pandora moths (Coloradia pandora Blake) on the Kaibab Plateau, Arizona (Saturniidae). J. Lepid. Soc. 38: 65.

Brudvig, L. A., E. I. Damschen, N. M. Haddad, D. J. Levey \& J. J. Tewksbury. 2015. The influence of habitat fragmentation on multiple plant-animal interactions and plant reproduction. Ecology 96: 2669-2678.

Brunet, J., Z. Larson-Rabin \& C. M. Stewart. 2012. The distribution of genetic diversity within and among populations of the Rocky Mountain columbine: The impact of gene flow, pollinators, and mating system. Int. J. Pl. Sci. 173: 484-494.

Buschbom, J., Y. Yanbaev \& B. Degen. 2011. Efficient longdistance gene flow into an isolated relict oak stand. J. Hered. 102: 464-472.

Cánovas, J. L., J. F. Jiménez, J. F. Mota \& P. S. Gómez. 2015. Genetic diversity of Viola cazorlensis Gand., an endemic species of Mediterranean dolomitic habitats: Implications for conservation. Syst. Biodivers. 13: 571-580.

Charlesworth, D. 2006. Evolution of plant breeding systems. Curr. Biol. 16: R726-R735.

Cole, C. T. 2003. Genetic variation in rare and common plants. Annual Rev. Ecol. Evol. Syst. 34: 213-237.

Cordeiro, N. J. \& H. F. Howe. 2003. Forest fragmentation severs mutualism between seed dispersers and an endemic African tree. Proc. Natl. Acad. Sci. U.S.A. 100: 14052-14056.

Damschen, E. I., L. A. Brudvig, N. M. Haddad, D. J. Levey, J. L. Orrock \& J. J. Tewksbury. 2008. The movement ecology and dynamics of plant communities in fragmented landscapes. Proc. Natl. Acad. Sci. U.S.A. 105: 1907819083.

Devoto, M., S. Bailey \& J. Memmott. 2011. The 'night shift': Nocturnal pollen-transport networks in a boreal pine forest. Ecol. Entomol. 36: 25-35.

Dewoody, J., J. D. Nason \& V. D. Hipkins. 2006. Mitigating scoring errors in microsatellite data from wild populations. Molec. Ecol. Notes 6: 951-957.

Do, C., R. S. Waples, D. Peel, G. M. Macbeth, B. J. Tillett \& J. R. Ovenden. 2014. NeEstimator v2: Re-implementation of software for the estimation of contemporary effective population size $\left(N_{e}\right)$ from genetic data. Molec. Ecol. Resources 14: 209-214.

Dyer, R. J. 2007. Powers of discerning: Challenges to understanding dispersal processes in natural populations. Molec. Ecol. 16: 4881-4882.
Earl, D. A. \& B. M. vonHoldt. 2012. STRUCTURE HARVESTER: A website and program for visualizing STRUCTURE output and implementing the Evanno method. Conservation Genet. Resources 4: 359-361.

Eckert, C. G., S. Kalisz, M. A. Geber, R. Sargent, E. Elle, P.-O. Cheptou, C. Goodwillie, et al. 2010. Plant mating systems in a changing world. Trends Ecol. Evol. 25: 35-43.

Ehrlich, P. R. \& P. H. Raven. 1969. Differentiation of populations. Science 165: 1228-1232.

Emer, C., M. Galetti, M. A. Pizo, P. R. Guimarães, S. Moraes, A. Piratelli \& P. Jordano. 2018. Seed-dispersal interactions in fragmented landscapes-A metanetwork approach. Ecol. Lett. 21: 484-493.

Evanno, G., S. Regnaut \& J. Goudet. 2005. Detecting the number of clusters of individuals using the software STRUCTURE: A simulation study. Molec. Ecol. 14: 2611-2620.

Fægri, K. \& L. van der Pijl. 1966. The Principles of Pollination Ecology. Pergamon Press, Oxford.

Fahrig, L. 2003. Effects of habitat fragmentation on biodiversity. Annual Rev. Ecol. Evol. Syst. 34: 487-515.

Falush, D., M. Stephens \& J. K. Pritchard. 2007. Inference of population structure using multilocus genotype data: Dominant markers and null alleles. Molec. Ecol. Notes 7: 574-578.

Fenster, C. B., W. S. Armbruster, P. Wilson, M. R. Dudash \& J. D. Thomson. 2004. Pollination syndromes and floral specialization. Annual Rev. Ecol. Evol. Syst. 35: 375-403.

Finger, A., C. N. Kaiser-Bunbury, C. J. Kettle, T. Valentin \& J. Ghazoul. 2014. Genetic connectivity of the moth pollinated tree Glionnetia sericea in a highly fragmented habitat. PLoS One 9: el11111.

Fischer, J. \& D. B. Lindenmayer. 2007. Landscape modification and habitat fragmentation: A synthesis. Global Ecol. Biogeogr. 16: 265-280.

Fox, R. 2013. The decline of moths in Great Britain: A review of possible causes. Insect Conservation Divers. 6: 5-19.

Fox, R., T. H. Oliver, C. Harrower, M. S. Parsons, C. D. Thomas \& D. B. Roy. 2014. Long-term changes to the frequency of occurrence of British moths are consistent with opposing and synergistic effects of climate and land-use changes. J. Appl. Ecol. 51: 949-957.

Frank, K. D. 2006. Effects of artificial night lighting on moths. Pp. 305-344 in C. Rich \& T. Longcore (editors), Ecological Consequences of Artificial Night Lighting. Island Press, Washington, D.C.

Franks, S. J., C. L. Richards, E. Gonzales, J. E. Cousins \& J. L. Hamrick. 2004. Multi-scale genetic analysis of Uniola paniculata (Poaceae): A coastal species with a linear, fragmented distribution. Amer. J. Bot. 91: 1345-1351.

Frick, T. B. \& D. W. Tallamy. 1996. Density and diversity of nontarget insects killed by suburban electric insect traps. Entomol. News 107: 77-82.

Gaiotto, F. A. 2003. Genetic structure, mating system, and long-distance gene flow in heart of palm (Euterpe edulis Mart.). J. Hered. 94: 399-406.

Gerber, S., J. Chadœuf, F. Gugerli, M. Lascoux, J. Buiteveld, J. Cottrell, A. Dounavi, et al. 2014. High rates of gene flow by pollen and seed in oak populations across Europe. PLoS One 9: E85130.

Ghazoul, J. 2005. Pollen and seed dispersal among dispersed plants. Biol. Rev. Cambridge Philos. Soc. 80: 413.

Gitzendanner, M. A. \& P. S. Soltis. 2000. Patterns of genetic variation in rare and widespread plant congeners. Amer. J. Bot. 87: 783-792.

Goldstein, P. Z. 2010. Life history of the imperial moth Eacles imperialis (Drury) (Saturniidae: Ceratocampinae) in New England, USA: Distribution, decline, and nutritional ecology of a relictual islandic population. J. Res. Lepidoptera 42: 34-49. 
Gómez, J. M. \& R. Zamora. 2000. Spatial variation in the selective scenarios of Hormathophylla spinosa (Cruciferae). Amer. Naturalist 155: 657-668.

Gonzalez, A., B. Rayfield \& Z. Lindo. 2011. The disentangled bank: How loss of habitat fragments and disassembles ecological networks. Amer. J. Bot. 98: 503-516.

Goudet, J. 1995. FSTAT (version 1.2): A computer program to calculate F-statistics. J. Hered. 86: 485.

Govindaraju, D. R. 1988. Relationship between dispersal ability and levels of gene flow in plants. Oikos 52: 31 .

Grant, V. 1983. The systematic and geographical distribution of hawkmoth flowers in the temperate North American flora. Bot. Gaz. 144: 429-449.

Grant, V. 1985. Additional observations on temperate North American hawkmoth flowers. Bot. Gaz. 146: 517-520.

Gregory, D. P. 1963. Hawkmoth Pollination in the Genus Oenothera. Ph.D. Dissertation, The Claremont Graduate School, Claremont, California.

Gregory, D. P. 1964. Hawkmoth pollination in the genus Oenothera. Aliso 5: 385-419.

Grivet, D., J. J. Robledo-Arnuncio, P. E. Smouse \& V. L. Sork. 2009. Relative contribution of contemporary pollen and seed dispersal to the effective parental size of seedling population of California valley oak (Quercus lobata, Née). Molec. Ecol. 18: 3967-3979.

Grömping, U. 2006. Relative importance for linear regression in R: The package relaimpo. J. Stat. Softw. 17: 1-27.

Guidugli, M. C., A. G. Nazareno, J. M. Feres, E. P. B. Contel, M. A. Mestriner \& A. L. Alzate-Marin. 2016. Small but not isolated: A population genetic survey of the tropical tree Cariniana estrellensis (Lecythidaceae) in a highly fragmented habitat. Heredity 116: 339-347.

Haber, W. A. \& G. W. Frankie. 1989. A tropical hawkmoth community: Costa Rican dry forest Sphingidae. Biotropica 21: 155 .

Haddad, N. M., L. A. Brudvig, J. Clobert, K. F. Davies, A. Gonzalez, R. D. Holt, T. E. Lovejoy, et al. 2015. Habitat fragmentation and its lasting impact on Earth's ecosystems. Sci. Advances 1: E1500052.

Hadley, A. S. \& M. G. Betts. 2009. Tropical deforestation alters hummingbird movement patterns. Biol. Lett. 5: 207-210.

Haldane, J. B. S. 1948. The theory of a cline. J. Genet. 48: 277-284.

Hamilton, M. B. \& J. R. Miller. 2002. Comparing relative rates of pollen and seed gene flow in the island model using nuclear and organelle measures of population structure. Genetics 162: 1897-1909.

Hamrick, J. L. \& M. J. W. Godt. 1996. Effects of life history traits on genetic diversity in plant species. Philos. Trans., Ser. B 351: 1291-1298.

Hardy, O. J. \& X. Vekemans. 2002. SPAGeDi: A versatile computer program to analyze spatial genetic structure at the individual or population levels. Molec. Ecol. Notes 2: 618-620.

Hedrick, P. W. 2005. A standardized genetic differentiation measure. Evolution 59: 1633-1638.

Herrera, C. M. \& P. Bazaga. 2008. Population-genomic approach reveals adaptive floral divergence in discrete populations of a hawk moth-pollinated violet. Molec. Ecol. 17: 5378-5390.

Homer, C., J. A. Dewitz, L. Yang, S. Jin, P. Danielson, G. Xian, J. Coulston, et al. 2015. Completion of the 2011 National Land Cover Database for the conterminous United States-Representing a decade of land cover change information. Photogramm. Engin. Remote Sensing 81: 345-354.

Hopkins, G. R., K. J. Gaston, M. E. Visser, M. A. Elgar \& T. M. Jones. 2018. Artificial light at night as a driver of evolution across urban-rural landscapes. Frontiers Ecol. Environm. 16: 472-479.
Hughes, M., M. Möller, T. J. Edwards, D. U. Bellstedt \& M. De Villiers. 2007. The impact of pollination syndrome and habitat on gene flow: A comparative study of two Streptocarpus (Gesneriaceae) species. Amer. J. Bot. 94: 1688-1695.

Jin, S., L. Yang, P. Danielson, C. Homer, J. Fry \& G. Xian. 2013. A comprehensive change detection method for updating the National Land Cover Database to circa 2011. Remote Sensing Environm. 132: 159-175.

Johnson, S. D. \& K. E. Steiner. 2000. Generalization versus specialization in plant pollination systems. Trends Ecol. Evol. 15: 140-143.

Jordano, P. 2010. Pollen, seeds and genes: The movement ecology of plants. Heredity 105: 329-330.

Jost, L. 2008. $G_{\mathrm{ST}}$ and its relatives do not measure differentiation. Molec. Ecol. 17: 4015-4026.

Karron, J. D., C. T. Ivey, R. J. Mitchell, M. R. Whitehead, R. Peakall \& A. L. Case. 2012. New perspectives on the evolution of plant mating systems. Ann. Bot. 109: 493-503.

Khasa, P. D., C. H. Newton, M. H. Rahman, B. Jaquish \& B. P. Dancik. 2000. Isolation, characterization, and inheritance of microsatellite loci in alpine larch and western larch. Genome 43: 439-448.

Knop, E., L. Zoller, R. Ryser, C. Gerpe, M. Hörler \& C. Fontaine. 2017. Artificial light at night as a new threat to pollination. Nature (Taipei) 548: 206.

Kovács-Hostyánszki, A., A. Espíndola, A. J. Vanbergen, J. Settele, C. Kremen \& L. V. Dicks. 2017. Ecological intensification to mitigate impacts of conventional intensive land use on pollinators and pollination. Ecol. Lett. 20: 673-689.

Kramer, A. T., J. B. Fant \& M. V. Ashley. 2011. Influences of landscape and pollinators on population genetic structure: Examples from three Penstemon (Plantaginaceae) species in the Great Basin. Amer. J. Bot. 98: 109-121.

Kremen, C., N. M. Williams, M. A. Aizen, B. Gemmill-Herren, G. LeBuhn, R. Minckley, L. Packer, et al. 2007. Pollination and other ecosystem services produced by mobile organisms: A conceptual framework for the effects of land-use change. Ecol. Lett. 10: 299-314.

Ladyman, J. A. R. 2005. Oenothera harringtonii Wagner, Stockhouse \& Klein (Colorado Springs evening-primrose): A technical conservation assessment. USDA Forest Service, Rocky Mountain Region. < https://www.fs.usda.gov/Internet/ FSE_DOCUMENTS/stelprdb5206869.pdf>, accessed 16 August 2019.

Lander, T. A., E. K. Klein, S. Stoeckel, S. Mariette, B. Musch \& S. Oddou-Muratorio. 2013. Interpreting realized pollen flow in terms of pollinator travel paths and land-use resistance in heterogeneous landscapes. Landscape Ecol. 28: 1769-1783.

Leishman, M. R. 1999. How well do plant traits correlate with establishment ability? Evidence from a study of 16 calcareous grassland species. New Phytol. 141: 487-496.

Lenormand, T. 2002. Gene flow and the limits to natural selection. Trends Ecol. Evol. 17: 183-189.

Leonarduzzi, C., S. Leonardi, P. Menozzi \& A. Piotti. 2012. Toward an optimal sampling effort for paternity analysis in forest trees: What do the raw numbers tell us? iForest Biogeosciences Forest. 5: 18-25.

Lewis, E. M. 2015. Differences in Population Genetic Structure in Hawkmoth- and Bee-pollinated Species of Oenothera (Onagraceae) Are More Pronounced at a Regional Scale. Master's Thesis, Northwestern University, Evanston, Illinois. Lewis, E. M., J. B. Fant, M. J. Moore, A. P. Hastings, E. L. Larson, A. A. Agrawal \& K. A. Skogen. 2016. Microsatellites for Oenothera gayleana and $O$. hartwegii subsp. filifolia (Onagraceae), and their utility in Section Calylophus. Appl. Pl. Sci. 4: 1500107. 
Linhart, Y. B. \& J. A. Mendenhall. 1977. Pollen dispersal by hawkmoths in a Lindenia rivalis Benth. population in Belize. Biotropica 9: 143.

Lowe, A. J., S. Cavers, D. Boshier, M. F. Breed \& P. M. Hollingsworth. 2015. The resilience of forest fragmentation genetics—no longer a paradox-we were just looking in the wrong place. Heredity 115: 97-99.

Lynch, M. \& K. Ritland. 1999. Estimation of pairwise relatedness with molecular markers. Genetics 152: 1753-1766.

Macgregor, C. J., M. J. O. Pocock, R. Fox \& D. M. Evans. 2014. Pollination by nocturnal Lepidoptera, and the effects of light pollution: A review. Ecol. Entomol. 40: 187-198.

Magrach, A., W. F. Laurance, A. R. Larrinaga \& L. Santamaria. 2014. Meta-analysis of the effects of forest fragmentation on interspecific interactions. Conservation Biol. 28: 1342-1348.

Meirmans, P. G. \& P. W. Hedrick. 2011. Assessing population structure: $F_{\mathrm{ST}}$ and related measures. Molec. Ecol. Resour. 11: 5-18.

Meirmans, P. G., J. Goudet, IntraBioDiv Consortium \& O. E. Gaggiotti. 2011. Ecology and life history affect different aspects of the population structure of 27 high-alpine plants. Molec. Ecol. 20: 3144-3155.

Millar, M. A., D. J. Coates \& M. Byrne. 2014. Extensive longdistance pollen dispersal and highly outcrossed mating in historically small and disjunct populations of Acacia woodmaniorum (Fabaceae), a rare banded iron formation endemic. Ann. Bot. 114: 961-971.

Müller, K. 2005. SeqState. Appl. Bioinformatics 4: 65-69.

Müller, K. 2006. Incorporating information from lengthmutational events into phylogenetic analysis. Molec. Phylogenet. Evol. 38: 667-676.

Nassar, J. M., J. L. Hamrick \& T. H. Fleming. 2001. Genetic variation and population structure of the mixed-mating cactus, Melocactus curvispinus (Cactaceae). Heredity 87: 69-79.

Nassar, J. M., J. L. Hamrick \& T. H. Fleming. 2003. Population genetic structure of Venezuelan chiropterophilous columnar cacti (Cactaceae). Amer. J. Bot. 90: 1628-1637.

Nemec, S. J. 1969. Use of artificial lighting to reduce Heliothis spp. populations in cotton fields. J. Econ. Entomol. 62: 1138-1140.

Nybom, H. 2004. Comparison of different nuclear DNA markers for estimating intraspecific genetic diversity in plants. Molec. Ecol. 13: 1143-1155.

Peakall, R. \& P. E. Smouse. 2012. GenAlEx 6.5: Genetic analysis in Excel. Population genetic software for teaching and research-An update. Bioinformatics 28: 2537-2539.

Petit, R. J. \& A. Hampe. 2006. Some evolutionary consequences of being a tree. Annual Rev. Ecol. Evol. Syst. 37: 187-214.

Pfrimmer, T. R. 1955. Experiments with light traps for control of the pink bollworm. U.S. Dept. Agric. Agric. Res. Serv. ARS-33-6.

Philipp, M., J. Böcher, H. R. Siegismund \& L. R. Nielsen. 2006. Structure of a plant-pollinator network on a pahoehoe lava desert of the Galápagos Islands. Ecography 29: 531-540.

Piñeiro, R., J. Fuertes Aguilar, M. Menezes de Sequeira \& G. Nieto Feliner. 2009. Low genetic diversity in the rare Madeiran endemic Armeria maderensis (Plumbaginaceae). Folia Geobot. 44: 65-81.

Potts, S. G., J. C. Biesmeijer, C. Kremen, P. Neumann, O. Schweiger \& W. E. Kunin. 2010. Global pollinator declines: Trends, impacts and drivers. Trends Ecol. Evol. 25: 345-353.

Pritchard, J. K., M. Stephens \& P. Donnelly. 2000. Inference of population structure using multilocus genotype data. Genetics 155: 945-959.

R Core Team. 2019. R: A Language and Environment for Statistical Computing. R Foundation for Statistical Computing, Vienna.
Rey, P. J., C. M. Herrera, J. Guitián, X. Cerdá, A. M. SanchezLafuente, M. Medrano \& J. L. Garrido. 2006. The geographic mosaic in predispersal interactions and selection on Helleborus foetidus (Ranunculaceae). J. Evol. Biol. 19: 21-34.

Rhodes, M. K., J. B. Fant \& K. A. Skogen. 2014. Local topography shapes fine-scale spatial genetic structure in the Arkansas Valley evening primrose, Oenothera harringtonii (Onagraceae). J. Hered. 105: 900-909.

Rhodes, M. K., J. B. Fant \& K. A. Skogen. 2017. Pollinator identity and spatial isolation influence multiple paternity in an annual plant. Molec. Ecol. 26: 4296-4308.

Robledo-Arnuncio, J. J. 2011. Wind pollination over mesoscale distances: An investigation with Scots pine. New Phytol. 190: 222-233.

Sala, O. E., F. S. Chapin III, J. J. Armesto, E. Berlow, J. Bloomfield, R. Dirzo, E. Huber-Sanwald, et al. 2000. Global biodiversity scenarios for the year 2100 . Science 287 : 1770-1774.

Scheper, J., M. Reemer, R. van Kats, W. A. Ozinga, G. T. J. van der Linden, J. H. J. Schaminée, H. Siepel, et al. 2014. Museum specimens reveal loss of pollen host plants as key factor driving wild bee decline in The Netherlands. Proc. Natl. Acad. Sci. U.S.A. 111: 17552-17557.

Schleuning, M., N. Farwig, M. K. Peters, T. Bergsdorf, B. Bleher, R. Brandl, H. Dalitz, et al. 2011. Forest fragmentation and selective logging have inconsistent effects on multiple animal-mediated ecosystem processes in a tropical forest. PLoS One 6: E27785.

Sezen, U. U., R. L. Chazdon \& K. E. Holsinger. 2005. Genetic consequences of tropical second-growth forest regeneration. Science 307: 891.

Sezen, U. U., R. L. Chazdon \& K. E. Holsinger. 2009. Proximity is not a proxy for parentage in an animal-dispersed Neotropical canopy palm. Proc. Biol. Sci. 276: 2037-2044.

Skogen, K. A., E. T. Hilpman, S. L. Todd \& J. B. Fant. 2012. Microsatellite primers in Oenothera harringtonii (Onagraceae), an annual endemic to the shortgrass prairie of Colorado. Amer. J. Bot. 99: e313-e316.

Skogen, K. A., T. Jogesh, E. T. Hilpman, S. L. Todd, M. K. Rhodes, S. M. Still \& J. B. Fant. 2016. Land-use change has no detectable effect on reproduction of a disturbanceadapted, hawkmoth-pollinated plant species. Amer. J. Bot. 103: 1950-1963.

Slatkin, M. 1985. Rare alleles as indicators of gene flow. Evolution 39: 53.

Sork, V. L. \& P. E. Smouse. 2006. Genetic analysis of landscape connectivity in tree populations. Landscape Ecol. 21: 821-836.

Sork, V. L., J. Nason, D. R. Campbell \& J. F. Fernandez. 1999. Landscape approaches to historical and contemporary gene flow in plants. Trends Ecol. Evol. 14: 219-224.

Sower, L. L., H. H. Shorey \& L. K. Gaston. 1970. Sex pheromones of noctuid moths. XXI. Light: Dark cycle regulation and light inhibition of sex pheromone release by females of Trichoplusia ni. Ann. Entomol. Soc. Amer. 63: 1090-1092.

Stockhouse, R. E., II 1973. Biosystematic Studies of Oenothera L. subgenus Pachylophus. Ph.D. Dissertation, Colorado State University, Fort Collins.

Svensson, A. M. \& J. Rydell. 1998. Mercury vapor lamps interfere with the bat defense of tympanate moths (Operophtera spp.; Geometridae). Anim. Behav. 55: 223226.

Totland, Ø. 2001. Environment-dependent pollen limitation and selection on floral traits in an alpine species. Ecology 82: 2233-2244. 
Vanbergen, A. J. \& The Insect Pollinators Initiative. 2013. Threats to an ecosystem service: Pressures on pollinators. Frontiers Ecol. Environm. 11: 251-259.

VanDerWal, J., L. Falconi, S. Januchowski, L. Shoo \& C. Storlie. 2013. Package 'SDMTools': Species Distribution Modeling Tools: Tools for processing data associated with species distribution modelling exercises. $<$ http://cran.rproject. org/web/packages/SDMTools/SDMTools.pdf $>$, accessed 5 May 2019.

Venables, W. N. \& B. D. Ripley. 2002. Modern Applied Statistics with S. Springer New York, New York.

Vogler, D. W. \& S. Kalisz. 2001. Sex among the flowers: The distribution of plant mating systems. Evolution 55: 202-204.

Wagner, D. L. 2012. Moth decline in the northeastern United States. News Lepid. Soc. 54: 52-56.

Wagner, W. L., R. E. Stockhouse II \& W. H. Klein. 1985. The Systematics and Evolution of the Oenothera cespitosa Species Complex (Onagraceae). Monogr. Syst. Bot. Missouri Bot. Gard. 12: 1-103.
Waples, R. S. \& C. H. I. Do. 2008. LDNE: A program for estimating effective population size from data on linkage disequilibrium. Molec. Ecol. Resour. 8: 753-756.

Weiner, C. N., M. Werner, K. E. Linsenmair \& N. Blüthgen. 2014. Land-use impacts on plant-pollinator networks: Interaction strength and specialization predict pollinator declines. Ecology 95: 466-474.

Weir, B. S. \& C. C. Cockerham. 1984. Estimating F-statistics for the analysis of population structure. Evolution 38: 1358-1370.

Whitehead, M. R., R. Lanfear, R. J. Mitchell \& J. D. Karron. 2018. Plant mating systems often vary widely among populations. Frontiers Ecol. Evol. 6: 38.

Whitlock, M. C. 2011. $G^{\prime}{ }_{\mathrm{ST}}$ and $D$ do not replace $F_{\mathrm{ST}}$. Molec. Ecol. 20: 1083-1091.

Winfree, R., I. Bartomeus \& D. P. Cariveau. 2011. Native pollinators in anthropogenic habitats. Annual Rev. Ecol. Evol. Syst. 42: 1-22.

Young, A., T. Boyle \& T. Brown. 1996. The population genetic consequences of habitat fragmentation for plants. Trends Ecol. Evol. 11: 413-418. 


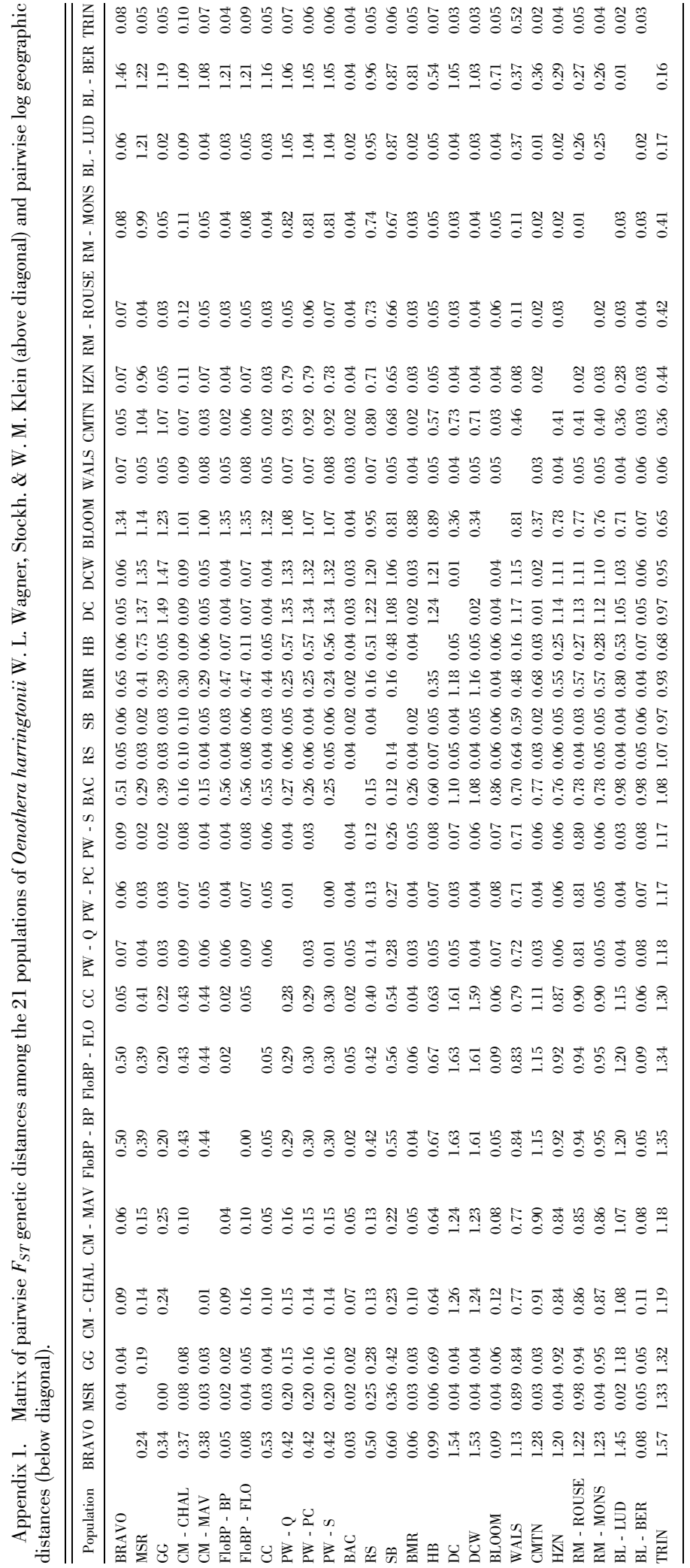

